Montana Tech Library

Digital Commons@ Montana Tech

Graduate Theses \& Non-Theses

Student Scholarship

Fall 2017

\title{
Geophysical Investigation of Dewatering in Lolo Creek, Southwest Missoula, Montana, USA
}

Akpofure Orubu

Montana Tech

Follow this and additional works at: http://digitalcommons.mtech.edu/grad_rsch

Part of the Other Engineering Commons

\section{Recommended Citation}

Orubu, Akpofure, "Geophysical Investigation of Dewatering in Lolo Creek, Southwest Missoula, Montana, USA" (2017). Graduate Theses \& Non-Theses. 138.

http://digitalcommons.mtech.edu/grad_rsch/138

This Publishable Paper is brought to you for free and open access by the Student Scholarship at Digital Commons @ Montana Tech. It has been accepted for inclusion in Graduate Theses \& Non-Theses by an authorized administrator of Digital Commons @ Montana Tech. For more information, please contact sjuskiewicz@mtech.edu. 


\section{Title}

Geophysical Investigation of Dewatering in Lolo Creek, Southwest Missoula, Montana, USA.

\section{Author names and affiliations}

Akpofure Orubu $^{1}$, Mohamed Khalil ${ }^{1}$, Bradley Rutherford ${ }^{1}$, Glenn Shaw ${ }^{1}$, Ali Gebril ${ }^{2}$, Camela Carstarphen $^{2}$

${ }^{1}$ Montana Tech, Department of Geophysical Engineering, Butte, MT, 59701, United States

${ }^{2}$ Montana Bureau of Mines and Geology, Butte, MT, 59701, United States

\section{Keywords}

Lolo Creek, dewatering, electrical resistivity tomography, spontaneous potential, multichannel analysis of surface waves, seismic refraction tomography 


\begin{abstract}
Electrical Resistivity Tomography (ERT), Spontaneous Potential (SP), Multichannel Analysis of Surface Waves (MASW) and Seismic Refraction Tomography methods have been used to provide valuable information on the seepage pathways leading to dewatering of Lolo Creek and the subsurface lithology of the area. Results from the MASW and seismic refraction tomography studies show a bedrock elevation of about $35 \mathrm{~m}$ close to Highway 93 and about $27 \mathrm{~m}$ at the end of the $288 \mathrm{~m}$ East-West seismic line running through Lewis and Clark Drive. ERT results show a shallow high resistive geolectric layer underlain by low resistive layers. The Eocene bedrock (mylonite) was found to have low resistivity between 180-400 $\Omega \mathrm{m}$. A geologic fault was inferred in a $360 \mathrm{~m}$ East-West ERT profile. SP measurements around the inferred fault indicate a zone of infiltration, with SP values between $-18 \mathrm{mV}$ to $-2 \mathrm{mV}$. A $1 \mathrm{D}$ depth velocity profile obtained from MASW survey located close to East-West ERT profile, indicates a low velocity subsurface between 0-39 m, which is interpreted to be fractured bedrock. This fractured shallow bedrock and associated fault work as a seepage path from the shallow to deep aquifer and could possibly account for dewatering of the Creek during low flow periods in the late-summer.
\end{abstract}




\section{Introduction}

Lolo Creek, located in Montana, is the northern-most major tributary of the Bitterroot River which empties into the Clark Fork River in Missoula, Montana. The Lolo Creek watershed covers an area of about $710 \mathrm{~km}^{2}$ and sits in the middle portion of the Bitterroot Mountains, southwest of Missoula (Figure 1). The Creek originates at the crest of the Bitterroot Range near the Idaho/Montana border at an elevation of about $1600 \mathrm{~m}$ above sea level and flows eastwards about $60 \mathrm{~km}$ to its confluence with the Bitterroot River at an elevation of about $960 \mathrm{~m}$ above sea level (John, 2004). The upper and middle portions of Lolo Creek sits in narrow, high gradient canyon while the lower portion broadens across the low-angle Lolo Creek alluvial fan (Chambers, 2016). The town of Lolo lies at the eastern end of the watershed.

Measured precipitation near the town of Lolo ranges from 33-38 cm/year, to $61 \mathrm{~cm} /$ year near the headwaters to $123 \mathrm{~cm} /$ year near the Idaho/Montana boarder (Chambers, 2016). Much greater annual precipitation occurs in the mountainous areas surrounding the valley, with wintertime precipitation falling mostly as snow (Larry et al., 2013). Significant accumulations of snowfall in the watershed's higher elevations create a larger reservoir of water released during melt periods resulting in annual peak flows in late spring, with annual lows in late summer (John 2004). The warmest months are also the driest months, which accordingly are periods with significant demands on groundwater and surface water for irrigation. Estimated water-use data for the year 2000 shows that water withdrawn for irrigation by Lolo-Bitterroot residents overwhelm other demands (Canon and Johnson, 2004).

Late-summer dewatering of Lolo Creek has been a reoccurring event in the areas between Highway 93 and Lolo Creek's confluence with the Bitterroot River (Figure 2). Recorded instances of dewatering start in the 80's and most recently includes 2007, 2011, 2012, 2013, 2015 and 2016 (Perry 2016; Pete, 2017). The dewatered reach has raised concerns about fish habitat and other riparian issues with water managers and local residents.

Carstaphen et al., (2016) and Chambers (2016) studied the magnitude of exchange between groundwater and surface-water in the lower reaches of Lolo Creek, and observed significant loss of surface water to groundwater as the Creek approached the Bitterroot Valley. Chambers also noted an increase in hydraulic gradient and the prevalence of coarse grained channel deposits as the Bitterroot Valley widened downstream. Possible contributing factors to 
the dewatering include surface water diversions, geomorphological changes that may separate the water table from the stream channel, lowering of the water table due to groundwater withdrawal, porous gravels that lose water to seek the level of the Bitterroot River, Lolo Creek responding to a lowered alluvial water level in the Bitterroot River valley, and the cumulative effect of climate change (Camela Carstaphen, personal communication, April 18, 2016).

This study is focused in the area between Highway 93 and the Bitterroot River, where Lolo Creek has been observed to have little or no flows during the late summer periods. We carried out this study with the aim of delineating dewatering pathways of the area using electrical and seismic methods. Electrical techniques have been extensively applied to geologic, hydrogeologic and dam seepage studies (Nwokebuihe et al., 2017; Atakpo, 2009; Chambers et al., 2006; Kumar et al., 2012; Khalil et al., 2015). Seismic methods have been extensively used for mapping shallow fault zones and bedrock (Ivanov et al., 2006; Ronczka et al., 2017; Improta et al., 2010).

\section{Geology and Hydrogeology of the Study Area}

According to a study by John (2004), the Geology of Lolo Creek watershed can be divided between Lolo Hot Springs towards the town of Lolo and above Lolo Hot Springs to the south of Lolo Creek. Between the town of Lolo and Lolo Hot Springs, Precambrian Belt Supergroup rock composed of limestone, dolomite and non-calcareous Belt Series rocks of the Wallace and Ravalli formations dominate (John, 2004; Lewis, 1998; Larry et al., 2013). Above Lolo Hot Springs to the south of Lolo Creek, the Bitterroot Mountains are composed primarily of metamorphic rocks (Phyllites, schists, quartz and quartzites) resulting from the intrusion of Tertiary granitic plutons on older bedrock units during tens of millions of years (John, 2004; Larry et al., 2013; Boer, 2002). Development of compressive tectonic forces about 110 million years ago and subsequent relaxation of the rocks when the compressive forces died out (40 to 50 million years ago) controlled the locations of areas down-dropped by faults relative to the surrounding mountains, which were filled by basin-fill deposits between 2 and 50 million years ago (John, 2004; Larry et al., 2013).

In the lower Lolo Creek area, Precambrian Belt Supergroup rock (Yb) forms the mountains and also underlie the valleys (Figure 3). The metamorphic rock (Mylonite) defines the 
Bitterroot Range Front (Larry et al., 2013). The valley floor is largely composed of unconsolidated alluvium, mostly sand and gravel but range in size from clay to boulders. Adjacent to the Lolo Creek flood plain are terrace deposits that form a narrow passageway towards the Bitterroot River (Chambers, 2016; Boer, 2002). Generalized cross sections of geologic units based on interpretations of water-well logs show a sequence of Precambrian bedrock overlain by Tertiary and Quaternary basin fill, with coarser-grained material as channel deposits within the younger quaternary alluvial fill (Figure 4). Figure 5 shows the exposed Mylonite bedrock to the south of the study area.

The principal aquifers in the Lolo Creek Watershed area occur in basin-fill deposits and fractured bedrock (Larry et al., 2013). Geologic units important to the hydrogeology of the LoloBitterroot area are given in Figure 6.

In the lower Lolo Creek area, unconsolidated alluvium associated with Lolo Creek and its tributaries form a nearly continuous unconfined basin-fill aquifer within $3 \mathrm{~m}$ of land surface to about $15 \mathrm{~m}$ below land surface. Coarse-grained basin fill deposits form deep-basin fill aquifers at depths greater than $15 \mathrm{~m}$ of land surface with multiple discontinuous layers of lowpermeability silt and clay locally confining water-bearing sand and gravel intervals. Fractures within Belt Supergroup form the bedrock aquifer (Larry et al., 2013).

Recharge to the shallow basin aquifer occurs by infiltration of precipitation, stream losses and leakage occur from irrigation ditches. Recharge sources to the deep basin-fill aquifer include downward leakage from shallow basin-fill aquifer and mountain-front recharge (Larry et al., 2013). Pumping test performed by the Montana Bureau of Mines and Geology (MBMG) on several wells drilled in shallow-basin fill, deep-basin fill and bedrock aquifers within lower Lolo Creek, suggests the deep-basin fill aquifer is in hydraulic connection with the bedrock aquifer but disconnected from the shallow aquifer (Ali Gebril, personal communication, April 24, 2017). Measured hydraulic conductivities and transmissivities for some wells in the study area are shown in Table 1. 


\section{Methods}

We conducted Electrical resistivity tomography (ERT), spontaneous potential (SP), multichannel analysis of surface waves (MASW) and seismic refraction tomography studies in the study area as shown in Figure 7. The theories behind these methods have been well discussed (Telford et al., 2010; Reynolds, 2011; Park et al, 1999).

\subsection{Electrical Resistivity Tomography (ERT)}

We acquired Electrical Resistivity Tomography (ERT) utilizing a Wenner electrode configuration in two stages during the summer of 2016. The first stage was for reconnaissance of the subsurface geology and structures. During the first stage, we measured resistivity profile P1 (Figure 7). P1 is an East-West trending 2D ERT profile having a length of $360 \mathrm{~m}$. Guided by the results of P1, we made a 3D resistivity survey of an area measuring $16,000 \mathrm{~m}^{2}$. In this second stage, we acquired nine parallel 2D resistivity profiles (S1-S9 in Figure 7) with each measuring $200 \mathrm{~m}$ in length and $10 \mathrm{~m}$ intervals between profiles. We collected the data using a Syscal R2 resistivity meter manufactured by IRIS instruments and measured the position of each electrode using a Garmin handheld Global Positioning System.

We inverted the acquired 2D resistivity data for P1 using RES2DINV by Geotomo after inputting the surface elevations and applying appropriate inversion parameters. $2 \mathrm{D}$ apparent resistivity data sets of profiles S1-S9 were combined into a 3D data set and inverted in a 3D manner using RES3DINV (Geotomo Software, 2014). The ERT data were relatively good quality with RMS error of $3.0 \%$ after seven iterations for P1 and 3.24\% after five iterations for the 3D inversion of the combined profiles S1-S9.

\subsection{Spontaneous Potential (SP)}

We acquired spontaneous potential (SP) data during the summer of 2016, using two saturated copper (II) sulfate non-polarizing electrodes and a high impedance voltmeter. The 128 SP station locations are shown in Figure 7. The SP stations spacing was $10 \mathrm{~m}$ from west to east, and $10 \mathrm{~m}$ from north to south. The base (reference) electrode was kept fixed while the lead electrode was moved progressively across the surface area. Measured SP data were subjected to drift correction relative to the base station. We used the drift-corrected SP data to generate an SP contour map using Surfer 10 software by Golden Software. 


\subsection{Multichannel Analysis of Surface Waves (MASW)}

We collected Multichannel Analysis of Surface Waves (MASW) data in proximity to Well 290586 and along ERT profile P1 in spring of 2017 (Figure 7). The seismic data was acquired using a 24 channel $8 \mathrm{~Hz}$ geophone array with $2 \mathrm{~m}$ spacing between geophones. A $9.07 \mathrm{~kg}$ sledge hammer was used as the seismic source at an offset of $10 \mathrm{~m}$ spacing from the first geophone. We measured the position of each profile using a Garmin handheld Global Positioning System. Profiles M1 to M6 were oriented in a North-South direction. MASW profiles (M1-M5) were acquired on $33 \mathrm{~m}, 100 \mathrm{~m}, 162 \mathrm{~m}, 225 \mathrm{~m}$ and $318 \mathrm{~m}$ marks along the West-East oriented ERT profile P1. The seismic data were analyzed using Surfseis3, a software developed by the Kansas Geological Survey. We generated a dispersion curve for each shot gather, assigned a surface location corresponding to the middle point of the receiver spread and inverted to give a 1D vertical shear wave velocity (Vs) and compressional wave (Vp) profile.

\subsection{Seismic Refraction Tomography}

We acquired refraction seismic tomography data along Lewis and Clark Drive in the summer of 2016. The Seismic data was acquired along a $288 \mathrm{~m}$ long East-West profile (Figure 7) using 144 geophone arrays (ninety-six $45 \mathrm{~Hz}$ and forty-eight $40 \mathrm{~Hz}$ geophones) with $2 \mathrm{~m}$ spacing between geophones. A $226.8 \mathrm{~kg}$ accelerated weight drop was used as the seismic source. 343 seismic stations were occupied, each having 3 shot records per station. We recorded the position of each seismic station using a Trimble Geo 7x Global Positioning System. We used Vista software by Schlumberger for the first-break picking and performed velocity calculation and modelling of the seismic section with the software package Rayfract (version 3.35) by Intelligent Resources Inc. The final result has been presented using the software package Surfer 10 by Golden Software.

\section{Results and Discussion}

We have used the available lithologs for wells 290586, 67465, and 67523 (Figure 8) to facilitate interpretation of results obtained from the ERT, Seismic Refraction Tomography, and MASW surveys.

The large length of ERT profile P1 (360 m) provided a good depth of investigation of 70 $\mathrm{m}$ (Figure 9 ) and $34 \mathrm{~m}$ for the 3D resistivity profile (Figure 10). However, the wide electrode 
spacing $(10 \mathrm{~m})$ resulted in low lateral and vertical resolution. ERT results show a high resistive top layer of 600-1200 $\Omega \mathrm{m}$ corresponding to the shallow dry surface layer above the water table. We interpreted this to be a mixture of quaternary cemented sand and gravel. This layer is underlain by low resistive layers of sands, gravels and clay having resistivities between 400-600 $\Omega \mathrm{m}$. Resistivity values decrease with depth, with variation in lateral and vertical resistivities suggesting that the properties of the basin-fill sediments is highly variable. Examination of resistivity distribution in P1 indicates a large horizontal discontinuity in resistivity layers. Matching between ERT profile P1 and well 290586 indicate that the low resistivity zone to the west $(<400 \Omega \mathrm{m}$ ) corresponds to the Tertiary Mylonite bedrock at $27 \mathrm{~m}$ depth in well 290586 (Figure 9). The bedrock was easy to drill through, highly fractured and has a high specific conductivity value (Camela Carstaphen, personal communication, April 24, 2017). The mylonite low resistivity zone is east dipping as described by Larry et al., (2013). From geological point of view, mylonite rocks result from recrystallization of mineral grains during rapid ductile deformation in a shear zone. Their polygonal to saturated grain boundaries differ from fine grained cataclastics, in which the grains have the sharp, angular shape characteristics of brittle fracturing (Twiss et al., 1992). Mylonite is characterized by low resistivity in the range of $50-$ $150 \Omega \mathrm{m}$ (Sun et al., 1997). We recognized an inferred fault zone on ERT profile P1 based on the high resistivity contrasts in the subsurface. We interpreted the areas between $240 \mathrm{~m}$ and $320 \mathrm{~m}$ on P1 as a seepage pathway, because SP anomalies within these areas show negative values of $18 \mathrm{mV}$ to $-2 \mathrm{mV}$ (Figure 9). Seepage infiltration locations are typically characterized by negative SP anomalies (Nwokebuihe et al., 2017; Revil 2013). The mylonite low resistivity zone is represented by a positive SP anomaly of $+2 \mathrm{mV}$ to $+18 \mathrm{mV}$. The positive SP signature of Mylonite has been observed also by (Heinson et al., 1999; Wishart et al., 2008).

The 3D resistivity inversion model (Figure 10) shows a high resistivity surface at the upper resistivity slice of 0-5 m. A low resistivity zone $(<400 \Omega \mathrm{m})$, labelled as "A" has an N-S extension and vertically extends from a depth of $10.8 \mathrm{~m}$ to $33.7 \mathrm{~m}$. We interpreted this low resistivity zone as highly fractured Mylonite zone.

The high hydraulic conductivity values of wells 290586 and 67523 in the study area (Table 1) support the idea of highly fractured and coarse grain aquifer. We observed that the water level in well 67523 (located about $300 \mathrm{~m}$ from the Creek) responds to the incremental 
stream flows of Lolo Creek (Figure 11). This suggests that the well is hydraulically connected to the Creek and lends credence to the highly fractured and coarse grain aquifer of the area.

MASW M6 (Figure 12 (f)) located about 45m north of Well 290586 show a depth to bedrock of about $27 \mathrm{~m}$ (943 m elevation). Also, lithologs from Well 290586 (Figure 8) show depth to top of bedrock at $26.8 \mathrm{~m}$ (943.2m elevation). This close match between both values indicate the suitability of the MASW as a non-invasive method to delineate depth to bedrock with high accuracy. We observe the bedrock to have an S-wave velocity (Vs) between 800990m/s and P-wave velocity (Vp) between 2050-2105m/s (Figure 12 (f)). Depth to bedrock in M1, M2, M3 and M4 is 34.8m, 35.5m, 36.8m and 37.5m respectively. M5 (Figure 12 (e)) shows a low velocity subsurface (Vs of $<600 \mathrm{~m} / \mathrm{s}$ and $\mathrm{Vp}<1800 \mathrm{~m} / \mathrm{s}$ ) to depths of about $39 \mathrm{~m}$, which we interpreted to be fractured bedrock. This fractured bedrock can serve as a conduit of surface water from the Creek to the bedrock aquifer.

Seismic refraction tomography results show an average depth to bedrock of $27 \mathrm{~m}(940 \mathrm{~m}$ elevation) along the profile (Figure 13). Velocity of the top of bedrock is approximately 2200 $\mathrm{m} / \mathrm{s}$. Well 67465 located about $50 \mathrm{~m}$ west of the seismic profile provided information about the lithology. We interpreted the first $5 \mathrm{~m}$ to be a mixture of clay, sand, and gravel saturated with water, while 5-27 $\mathrm{m}$ was interpreted to be a mixture of water saturated sand and gravel.

\section{Conclusions}

Electrical Resistivity Tomography (ERT), Spontaneous Potential (SP), Multichannel Analysis of Surface Waves (MASW), and seismic refraction surveys were carried out in lower Lolo Creek to investigate dewatering pathways and to provide valuable information on the subsurface geology. 2D and 3D resistivity results show a resistive shallow subsurface underlain by a low resistivity subsurface. Resistivity of the subsurface decreased with depth. We observed that the contact between basin fill sediments and bedrock could not be resolved by electrical resistivity. MASW results (M1 - M4) show the bedrock close to Highway 93 has a depth of about $35 \mathrm{~m}$ while M6 and lithologs from 290586 show a depth of about $27 \mathrm{~m}$ close to Lolo Creek. Seismic refraction tomography results along the East-West Lewis and Clark Drive show depth to bedrock at $27 \mathrm{~m}$. We observed the bedrock to have a low resistivity (180-485 $\Omega \mathrm{m})$. This bedrock is interpreted as mylonite. A geologic fault was inferred along P1. Spontaneous Potential measurements around the interpreted fault show high negative anomalies, indicating a 
zone of infiltration. M5, which shows the 1D depth velocity profile (of 318 m mark on P1), indicates a low velocity subsurface which we interpreted to be fractured bedrock. The fractured shallow Mylonite bedrock and associated fault work as a seepage path from the shallow to deep aquifer and could possibly account for dewatering of the Creek during low flow periods in the late-summer. The high hydraulic conductivity values of wells 290586 and 67523 in the study area (Table 1) support the idea of highly fractured and coarse grain aquifer. The response of water level in well 67523 to incremental discharge of Lolo Creek suggests the area is in hydraulic connection with the stream.

\section{Acknowledgements}

The 2016 Montana Tech Geology and Geophysics field students, Brad Rutherford, Mo Li and Zhou Zhaoming helped collect data for the project. The Geophysical Engineering Department at Montana Tech provided all geophysical equipment and logistics for field work. 


\section{References}

Boer, B. R. (2002). Septic-derived nutrient loading to the groundwater and surface water in Lolo Montana. University of Montana Graduate Thesis, 194 pp.

Cannon, M. R., \& Johnson, D. R. (2004). Estimated water use in Montana in 2000. U.S. Geol. Surv. Sci. Invest. Rep., 2004-5223, 50 pp.

Carstarphen, C., Wheaton, J. Chambers M. \& Gebril, A. (2016, October). How does the stream from wet to dry? Poster session presented at the Annual Convention of the American Water Resources Association, Fairmont, Montana.

Chambers, J. E., Kuras, O., Meldrum, P. I., Ogilvy, R. D., \& Hollands, J. (2006). Electrical resistivity tomography applied to geologic, hydrogeologic, and engineering investigations at a former waste-disposal site. Geophysics, 71(6), B231-B239.

Chambers, M. (2016). Several Methods to Assess Groundwater Surface-water Interactions in Lolo Creek, Montana. Montana Tech Graduate Theses \& Non-Theses, 103 pp.

Edmund, A. (2009). Hydrogeological deductions from geoelectric survey in Uvwiamuge and Ekakpamre communities, Delta State, Nigeria. International Journal of Physical Sciences, 4(9), 477-485.

Heinson, G., White, A., Constable, S., \& Key, K. (1999). Marine self-potential exploration. Exploration Geophysics, 30(2), 1-4.

Improta, L., Ferranti, L., De Martini, P. M., Piscitelli, S., Bruno, P. P., Burrato, P., Civico, R., Giocoli, A., Lorio, M., D’addezio, G., \& Maschio, L. (2010). Detecting young, slow-slipping active faults by geologic and multidisciplinary high-resolution geophysical investigations: $\mathrm{A}$ case study from the Apennine seismic belt, Italy. Journal of Geophysical Research: Solid Earth, 115(B11).

Ivanov, J., Miller, R. D., Lacombe, P., Johnson, C. D., \& Lane Jr, J. W. (2006). Delineating a shallow fault zone and dipping bedrock strata using multichannel analysis of surface waves with a land streamer. Geophysics, 71(5), A39-A42.

John, Z. (2004). Lolo Creek Resource Assessment: A report on the condition, status and land use history of the Lolo Creek Watershed, Missoula County, Montana. Montana Trout, Missoula, MT.

Khalil, M. A., \& Santos, F. M. (2015). Geophysical evidence for the hydro-tectonic origin of the Sabkha El Sheikh Zwayed Lake and the shallow fresh water supplies, Northern Sinai, Egypt. Near Surface Geophysics, 13(1), 93-101.

Larry, N.S., John, I.L., Thomas, W.P. (2013). Groundwater Resources of the Lolo-Bitterroot Area Part A: Mineral, Missoula, and Rivalli Counties, Montana. Montana Bureau of Mines and Geology, Montana Groundwater Assessment Atlas No.4 
Lewis, R.S. (1998). Preliminary geologic map of the Montana part of the Missoula West 30' $x$ 60' quadrangle. Montana Bureau of Mines and Geology open file report 373, 20.p, 1 sheet, scale 1:100,000.

Nwokebuihe, S. C., Alotaibi, A. M., Elkrry, A., Torgashov, E. V., \& Anderson, N. L. (2016). Dam Seepage Investigation of an Earthfill Dam in Warren County, Missouri Using Geophysical Methods. AIMS Geosciences, 3(1), 1-13

Park, C. B., Miller, R. D., \& Xia, J. (1999). Multichannel analysis of surface waves. Geophysics, 64(3), 800-808.

Perry, N. (2016, August 24). Lolo Creek runs dry again. Missoulian News Paper Online. Retrieved from http://missoulian.com/news/local/lolo-creek-runs-dry-again/article_b9435deda451-5798-9b71-0f18907ade9f.html.

Peter, F. (2017, February 21). Lolo Creek's hitting rock bottom and the state wants to find out why. Missoulian News Paper Online. Retrieved from http://missoulian.com/news/local/lolocreek-s-hitting-rock-bottom-and-the-state-wants/article_83d3136c-ac00-5979-8b6f2fb90dbe5046.html.

Ramachandran, K., Tapp, B., Rigsby, T., \& Lewallen, E. (2012). Imaging of Fault and Fracture Controls in the Arbuckle-Simpson Aquifer, Southern Oklahoma, USA, through Electrical Resistivity Sounding and Tomography Methods. International Journal of Geophysics 2.

Revil, A., \& Jardani, A. (2013). The self-potential method: Theory and applications in environmental geosciences. Cambridge University Press.

Reynolds, J. M. (2011). An introduction to applied and environmental geophysics. John Wiley \& Sons.

Ronczka, M., Hellman, K., Günther, T., Wisén, R., \& Dahlin, T. (2017). Electric resistivity and seismic refraction tomography: a challenging joint underwater survey at Äspö Hard Rock Laboratory. Solid Earth, 8(3), 671.

Sun, Y., Wan, L., \& Guo, L. Z. (1997). Study on the mylonite of the shallow structure level in Southeastern China. In Proceedings of the 30th International Geological Congress: Structural geology and geomechanics, Vol. 14, pp. 66-73

Telford, W.M., Geldart, L.P., \& Sheriff, R.E. (2010). Applied Geophysics (Vol. 2). Cambridge University Press, Cambridge.

Twiss, R. J., \& Moores, E. M. (1992). Structural Geology. Freeman, New York, 532 pp.

Wishart, D. N., Slater, L. D., \& Gates, A. E. (2008). Fracture anisotropy characterization in crystalline bedrock using field-scale azimuthal self potential gradient. Journal of Hydrology, 358(1), 35-45. 


\section{Figure Captions}

Figure 1. Lolo Creek Watershed, southwest of Missoula, Montana. Lolo Creek flows from west to East, draining into the Bitterroot River.

Figure 2. Lolo Creek discharge below Highway 93, Lolo, Montana. (a) Discharge recorded from February to early December, 2016, showing little to no flow from late-July to early October. (b) Lolo Creek channel in August, 2016. (c) Same channel, dry, August, 2016. Lolo Creek discharge data are from MBMG's Surface Water Assessment and Monitoring Program database. (Photo credit: Camela Carstaphen, MBMG).

Figure 3. Geologic map of study area (after Lewis 1998). Lines of cross-sections A-A' (Fig. 4) and B-B' (Fig 5) are shown.

Figure 4. Geologic cross section A-A' based on interpretations of water-well logs

Figure 5. Geologic cross section B-B' obtained from well logs showing Quaternary (Qsc) and Tertiary basin fill sediments (Ts) underlain by Tertiary and Cretaceous igneous rocks. Tertiary mylonite defines the Bitterroot Range Front (after Larry et al., 2013).

Figure 6. Geologic units important to the hydrogeology of the Lolo-Bitterrot Area (after Larry et al., 2013)

Figure 7. Data acquisition map of study area where Lolo Creek has been observed to have gone completely dry during the late summer periods. Lolo Creek flows from west to East. The satellite image was obtained from Google Earth. Image was taken by Google on 07/07/2014.

Figure 8. Lithologs from Well 290586, 67465 and 67465. Well 290586 was advanced into bedrock at a depth of $27 \mathrm{~m}$. Data are from MBMG's Groundwater Information Center (GWIC) database.

Figure 9. 2D ERT Profile P1 with MASW positions and SP anomaly map. Well 290586 drilled to bedrock at about $226 \mathrm{~m}$ to the south of ERT profile is shown. Data from well 290586 are from MBMG's Groundwater Information Center (GWIC) database.

Figure 10. 3D Inversion model obtained by combining data sets of ERT profiles $\mathrm{S} 1$ - S9 showing depth slices; 0-5 m, 5-10.8 m, 10.8-17.4 m, 17.4-25.0 m, and 25-33.7 m. Location of Well 67465 and corresponding lithologs are shown. Data for Well 67465 is from MBMG's Groundwater Information Center (GWIC) database.

Figure 11. Static water level for Well 67523 responds to the incremental stream flow of Lolo Creek. Periods shown are from August 4th to December 12th, 2016. Data are from MBMG's Groundwater Information Center (GWIC) database.

Figure 12. MASW results showing $1 \mathrm{D}$ shear wave $\left(\mathrm{V}_{\mathrm{S}}\right)$ and compressional wave $(\mathrm{Vp})$ velocity profiles. (a) M1 acquired at $33 \mathrm{~m}$ mark along P1. (b) M2 acquired at $100 \mathrm{~m}$ mark along P1. (c) M3 acquired at 162 $\mathrm{m}$ mark along P1. (d) M4 acquired at $225 \mathrm{~m}$ mark along P1. (d) M5 acquired at $318 \mathrm{~m}$ mark along P1. (d) M6 acquired in close proximity to Well 290586. Green marker on figure indicate interpreted depth to top of rock. M5 shows a low velocity subsurface compared to M1, M2, M3, M4, and M6.

Figure 13. Velocity profile obtained from refraction seismic tomography using wavepath eikonal traveltime inversion (WET). Well 67465 located about $50 \mathrm{~m}$ west of the seismic profile is shown. Data for well 67465 are from MBMG's Groundwater Information Center (GWIC) database. 
Table 1. Hydraulic conductivities and transmissivities for some wells in Lolo, Montana.

\begin{tabular}{|l|l|l|l|}
\hline $\begin{array}{l}\text { Well } \\
\text { Number }\end{array}$ & $\begin{array}{l}\text { Saturated } \\
\text { Thickness } \\
(\mathrm{m})\end{array}$ & $\begin{array}{l}\text { Transmissivity } \\
\left(\mathrm{m}^{2} / \mathrm{d}\right)\end{array}$ & $\begin{array}{l}\text { Hydraulic } \\
\text { conductivity } \\
(\mathrm{m} / \mathrm{d})\end{array}$ \\
\hline 290661 & 24 & 24521 & 1,006 \\
\hline 67523 & 11 & 22770 & 2,134 \\
\hline 290586 & 20 & 39847 & 2,011 \\
\hline
\end{tabular}

Source: Ali Gebril, MBMG 


\section{Illustrations}

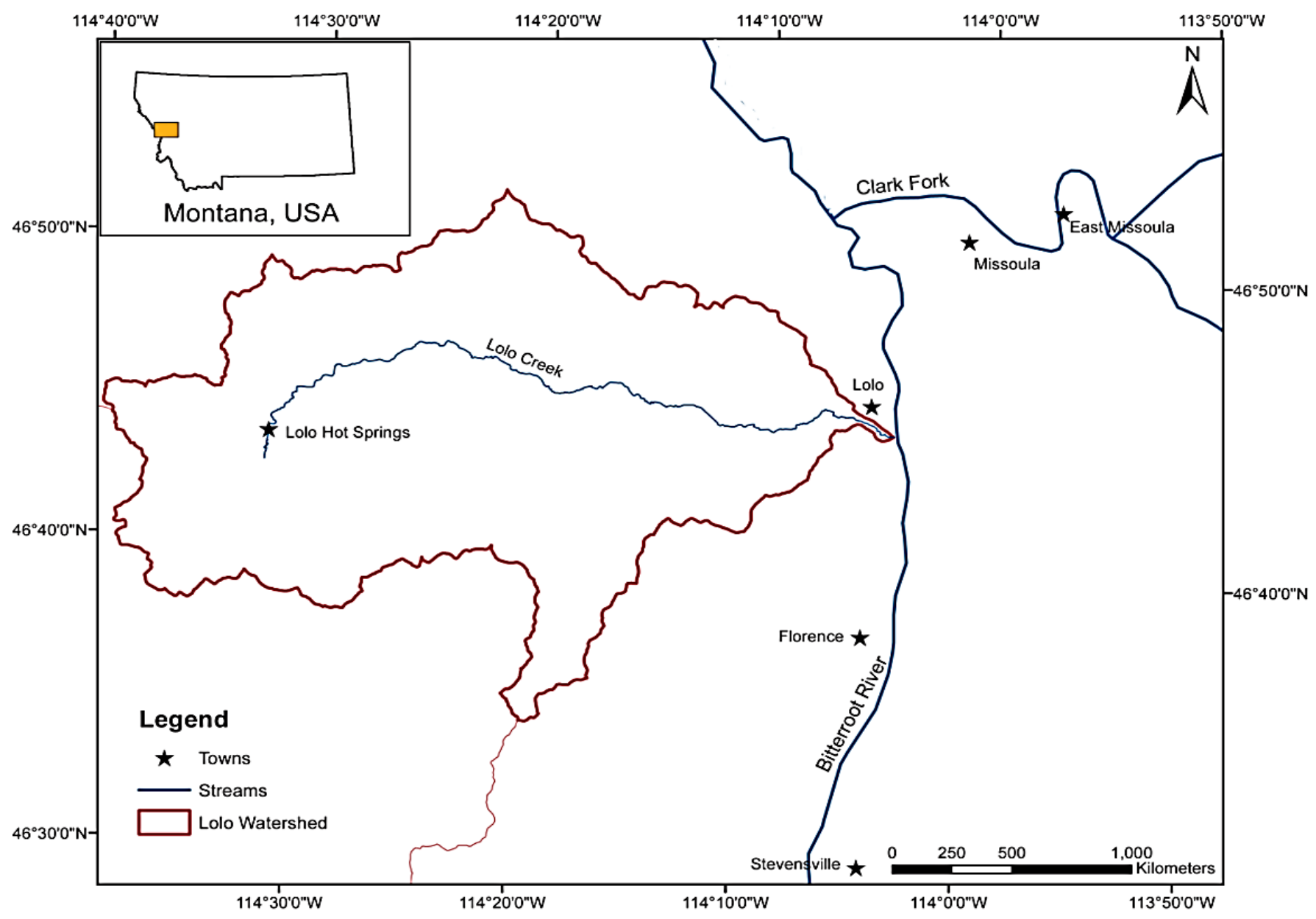

Figure 1. Lolo Creek Watershed, southwest of Missoula, Montana. Lolo Creek flows from west to East, draining into the Bitterroot River. 

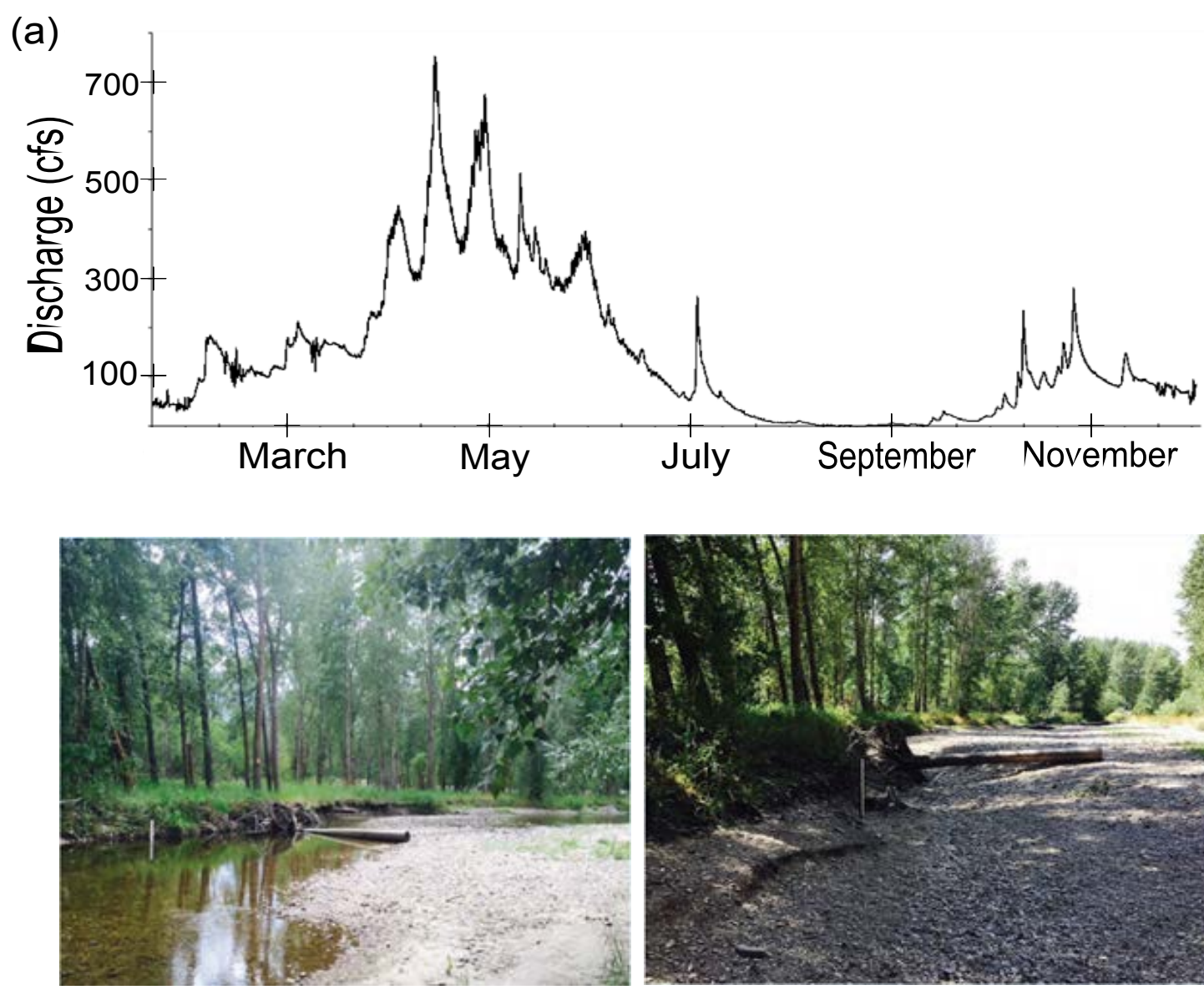

(b)

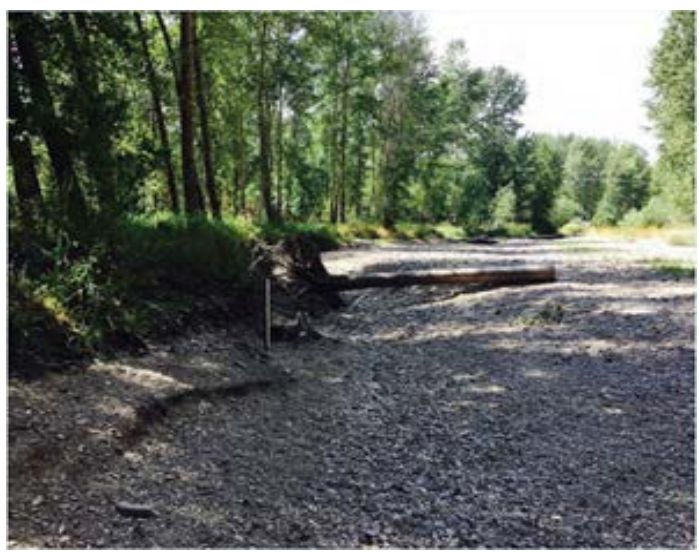

(c)

Figure 2. Lolo Creek discharge below Highway 93, Lolo, Montana. (a) Discharge recorded from February to early December, 2016, showing little to no flow from late-July to early October. (b) Lolo Creek channel in early August, 2016. (c) Same channel, dry, in late August, 2016. Lolo Creek discharge data are from MBMG's Surface Water Assessment and Monitoring Program database. (Photo credit: Camela Carstaphen, MBMG). 


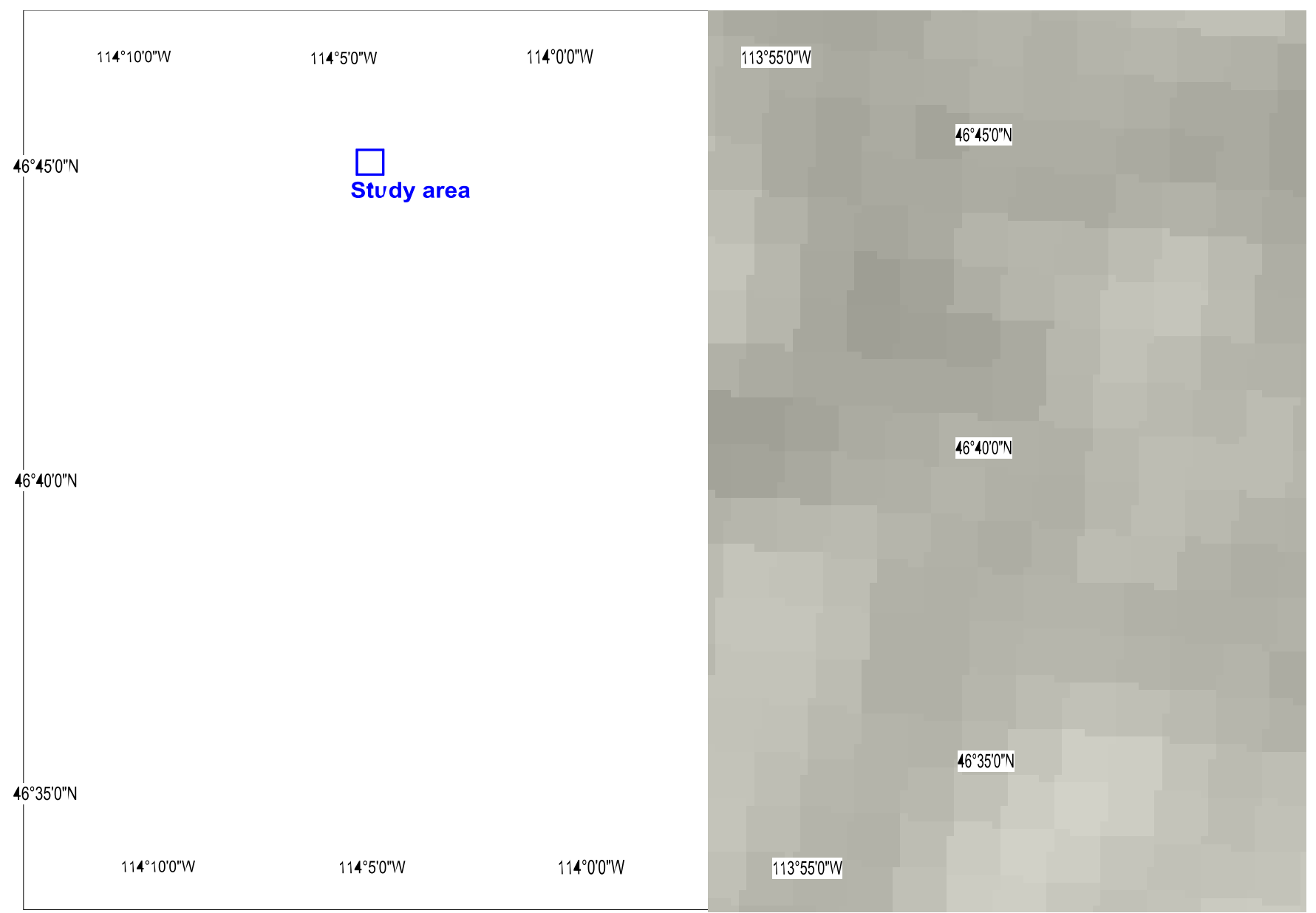

Figure 3. Geologic map of study area (after Lewis 1998). Lines of cross-sections A-A' (Fig. 4) and B-B' (Fig5) are shown. 
Figure 4. Geologic cross section A-A' based on interpretations of water-well logs 


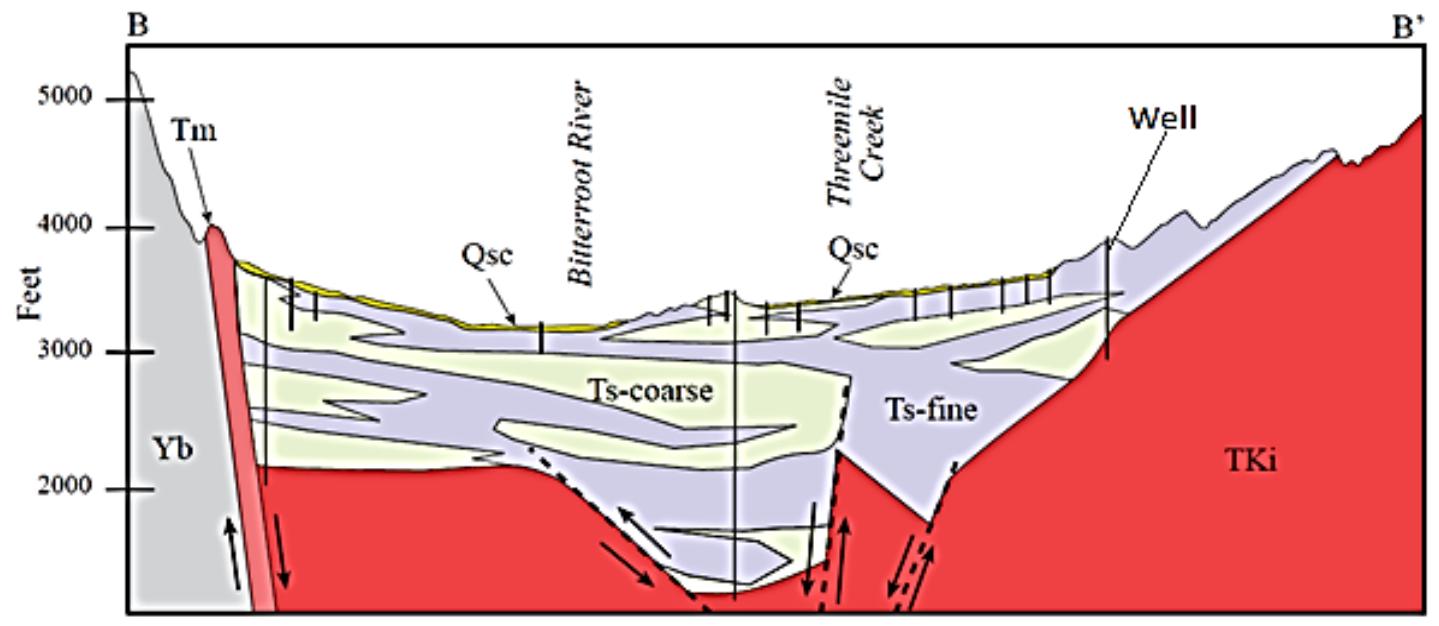

Figure 5. Geologic cross section B-B' obtained from well logs showing Quaternary (Qsc) and Tertiary basin fill sediments (Ts) underlain by Tertiary and Cretaceous igneous rocks. Tertiary mylonite defines the Bitterroot Range Front (after Larry et al., 2013). 


\begin{tabular}{|c|c|c|c|}
\hline Period & $\begin{array}{l}\text { Geologic } \\
\text { Units }\end{array}$ & Characteristics & Hydrologic Units \\
\hline \multirow[t]{2}{*}{ Quaternary } & \multirow[t]{2}{*}{$\begin{array}{l}\text { Sediments - } \\
\text { coarse } \\
\text { grained/fine } \\
\text { grained }\end{array}$} & $\begin{array}{l}\text { Coarse-grained: Light to medium brown } \\
\text { and grayish brown sand and gravel; some } \\
\text { silt and clay; along active stream valleys } \\
\text { and areas of sheetwash; contains minor } \\
\text { amount of colluvium; thicknesses average } \\
50 \mathrm{ft} \text {, but reach } 250 \mathrm{ft} \text { in paleochannels in } \\
\text { the Clark Fork River valley; can yield } \\
\text { significant quantities of groundwater. }\end{array}$ & $\begin{array}{l}\text { Mostly shallow basin-fill } \\
\text { aquifer, deep basin-fill aquifer } \\
\text { where thicker than } 75 \mathrm{ft}\end{array}$ \\
\hline & & $\begin{array}{l}\text { Fine-grained: Grayish brown, light to } \\
\text { dark yellowish brown gravelly silt, light } \\
\text { pink silt and sand, and silty and/or clayey } \\
\text { gravel; thicknesses range from } 5 \text { to } 140 \\
\mathrm{ft} \text {; generally does not yield water. }\end{array}$ & Non-aquifer basin-fill unit \\
\hline & & unconformity & \\
\hline \multirow[t]{2}{*}{ Tertiary } & $\begin{array}{l}\text { Sedimentary } \\
\text { rocks: coarse } \\
\text { grained and } \\
\text { fine grained }\end{array}$ & $\begin{array}{l}\text { Yellowish brown to light gray pebbly } \\
\text { sandstone, pebble and cobble } \\
\text { conglomerate; uncemented to moderately } \\
\text { cemented; light tan to gray claystone and } \\
\text { siltstone; rare carbonaceous shale and } \\
\text { lignite; sandstone and conglomerate yield } \\
\text { adequate supplies of water to wells for } \\
\text { household use. }\end{array}$ & $\begin{array}{l}\text { Mostly deep basin-fill aquifer, } \\
\text { shallow basin-fill aquifer where } \\
\text { within } 75 \mathrm{ft} \text { of land surface }\end{array}$ \\
\hline & Mylonite & $\begin{array}{l}\text { East- and southeast-dipping zone of well } \\
\text { foliated, erosionally resistant } \\
\text { metamorphic rocks that define the } \\
\text { Bitterroot Range front. }\end{array}$ & Bedrock \\
\hline \multirow[t]{2}{*}{$\begin{array}{l}\text { Upper } \\
\text { Cretaceous to } \\
\text { Eocene }\end{array}$} & Igneous & $\begin{array}{l}\text { White to pink, medium- to coarse-grained } \\
\text { granular and porphyritic intrusive rocks; } \\
\text { lesser amounts of volcanic rocks; where } \\
\text { fractured, the rocks can provide adequate } \\
\text { supplies of water for household use. }\end{array}$ & Bedrock \\
\hline & & unconformity & \\
\hline \multirow[t]{2}{*}{ Paleozoic } & $\begin{array}{l}\text { Various } \\
\text { sedimentary } \\
\text { formations }\end{array}$ & $\begin{array}{l}\text { Sandstone, quartzite, shale, limestone, } \\
\text { and dolomite of various formations; the } \\
\text { rocks provide inadequate to minimally } \\
\text { adequate water to wells for household } \\
\text { uses. }\end{array}$ & Bedrock \\
\hline & & unconformity & \\
\hline Proterozoic & $\begin{array}{l}\text { Belt } \\
\text { Supergroup }\end{array}$ & $\begin{array}{l}\text { Metamorphosed sandstone, shale, } \\
\text { siltstone, limestone, and dolomite of } \\
\text { various formations; where fractured, the } \\
\text { rocks can provide adequate supplies of } \\
\text { water for household use. }\end{array}$ & Bedrock \\
\hline
\end{tabular}

Figure 6. Geologic units important to the hydrogeology of the Lolo-Bitterrot Area (after Larry et al., 2013) 


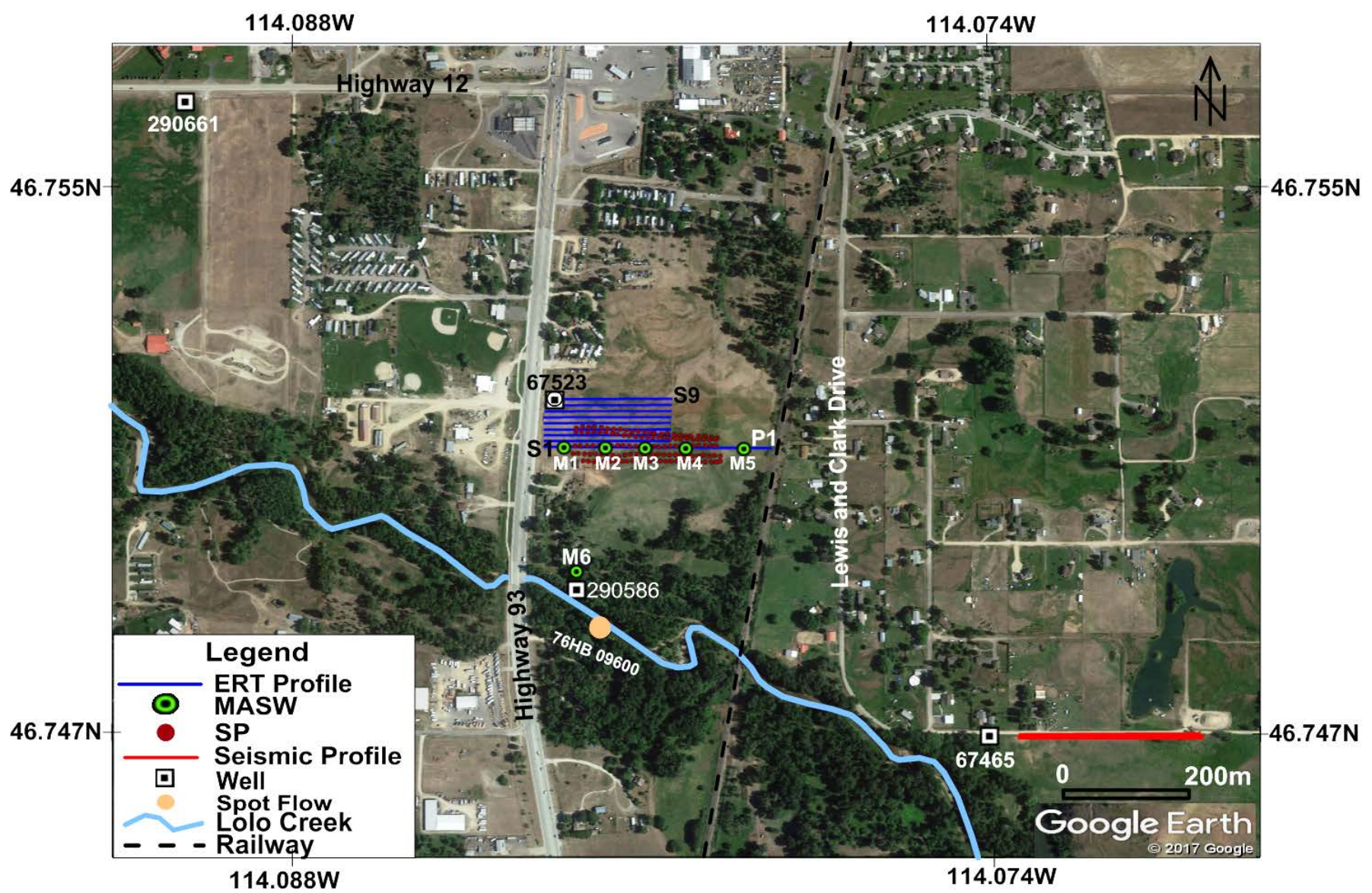

Figure 7. Data acquisition map of study area where Lolo Creek has been observed to have gone completely dry during the late summer periods. Lolo Creek flows from west to East. The satellite image was obtained from Google Earth. Image was taken by Google on 07/07/2014. 


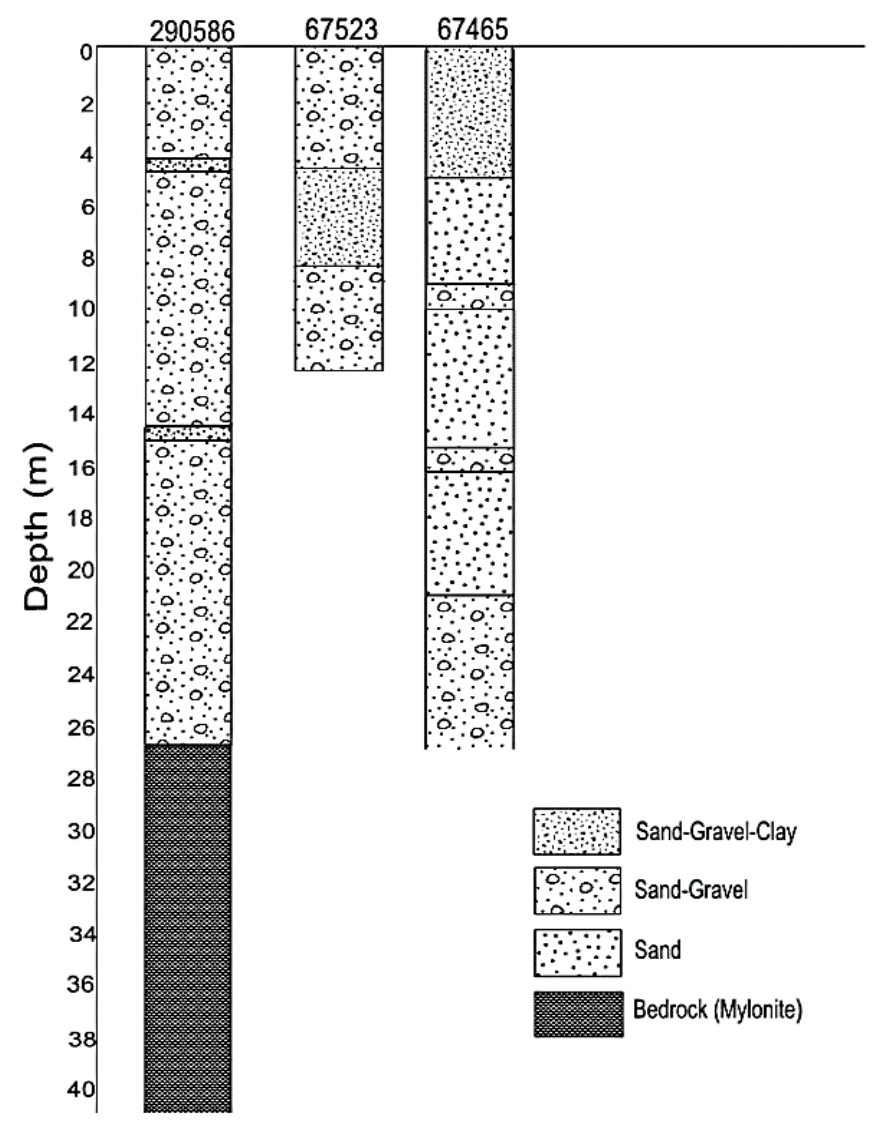

Figure 8. Lithologs from Well 290586, 67465 and 67465. Well 290586 was advanced into bedrock at a depth of $27 \mathrm{~m}$. Data are from MBMG's Groundwater Information Center (GWIC) database. 


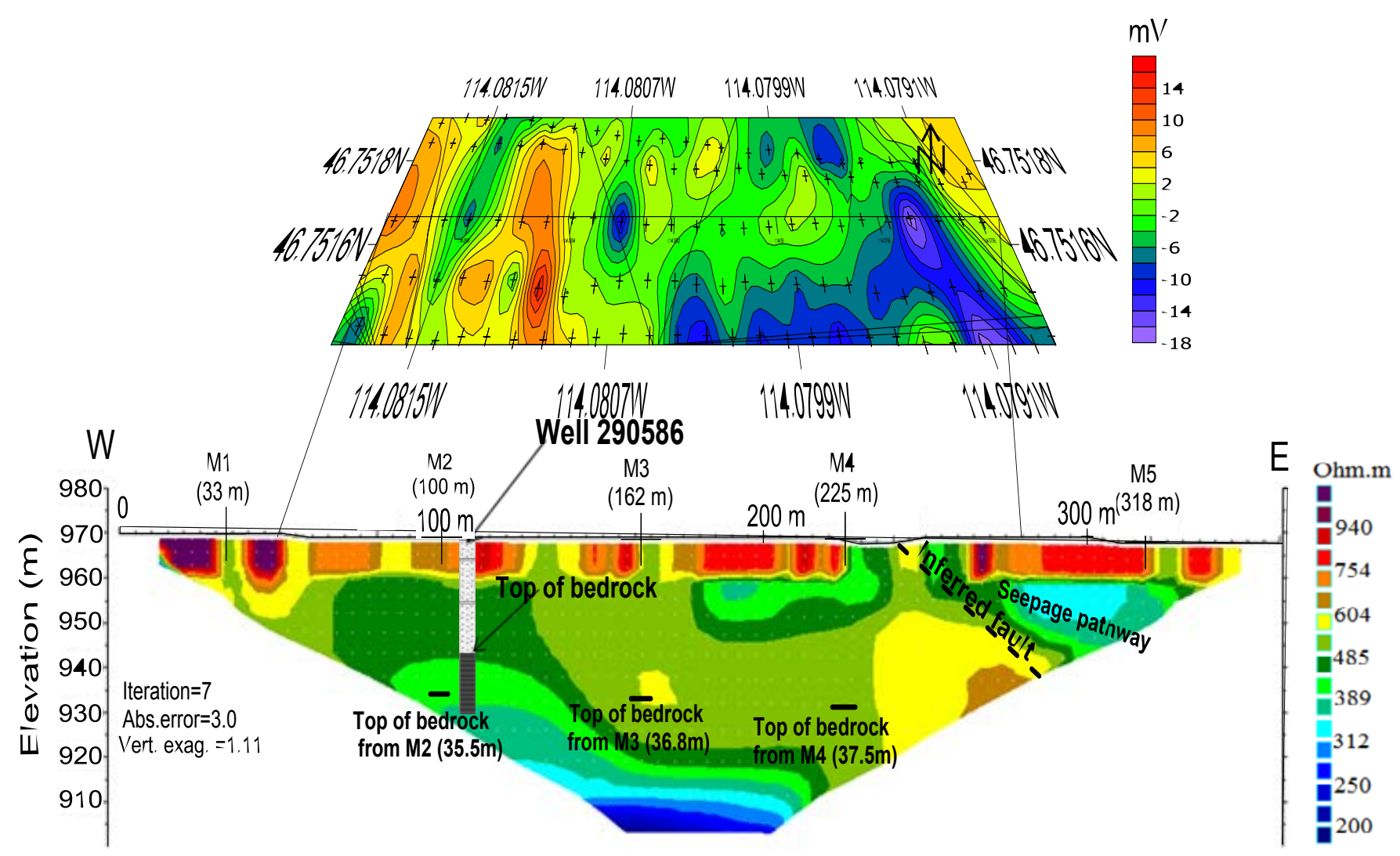

Figure 9. 2D ERT Profile P1 with MASW positions and SP anomaly map. Well 290586 drilled to bedrock at about $226 \mathrm{~m}$ to the south of ERT profile is shown. Data from well 290586 are from MBMG's Groundwater Information Center (GWIC) database. 


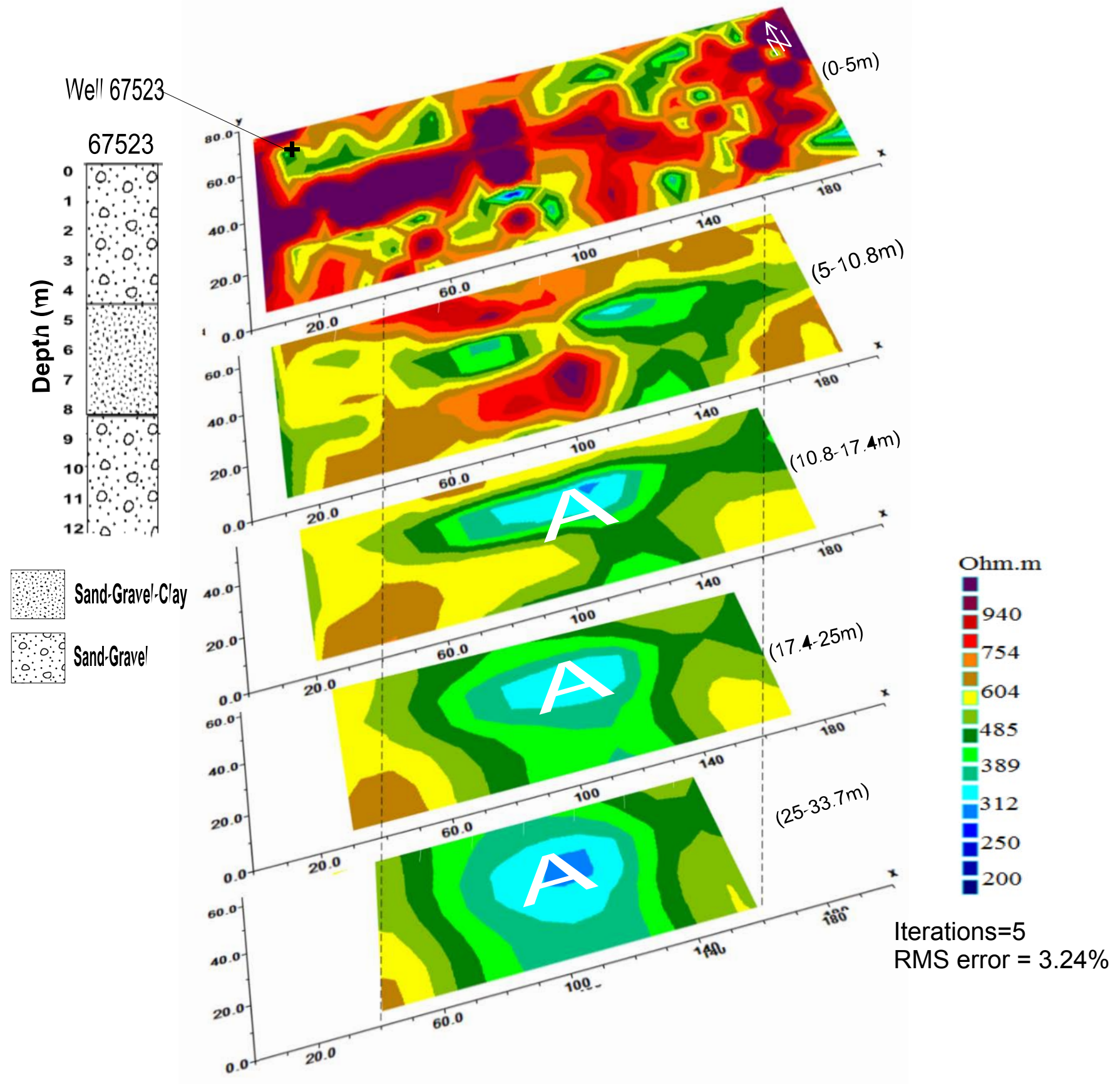

Figure 10. 3D Inversion model obtained by combining data sets of ERT profiles $\mathrm{S} 1$ - S9 showing depth slices; 0-5 m, 5-10.8 m, 10.8-17.4 m, 17.4-25.0 m, and 25-33.7 m. Location of Well 67465 and corresponding lithologs are shown. Data for Well 67465 is from MBMG's Groundwater Information Center (GWIC) database. 


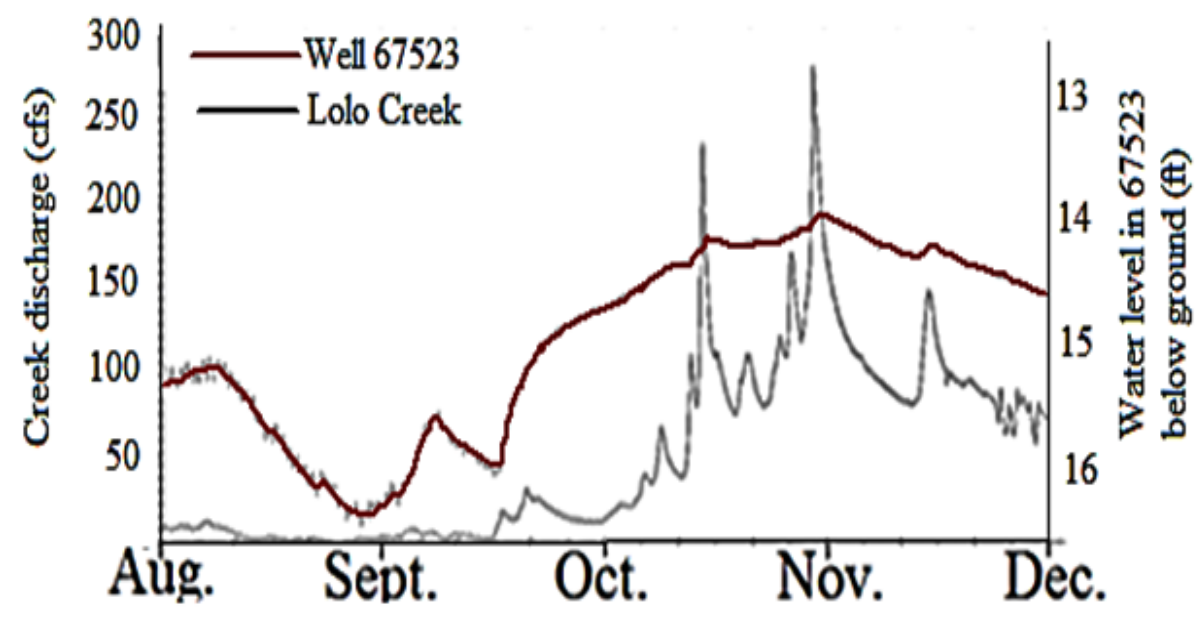

Figure 11. Static water level for Well 67523 responds to the incremental stream flow of Lolo Creek. Periods shown are from August 4th to December 12th, 2016. Data are from MBMG's Groundwater Information Center (GWIC) database. 

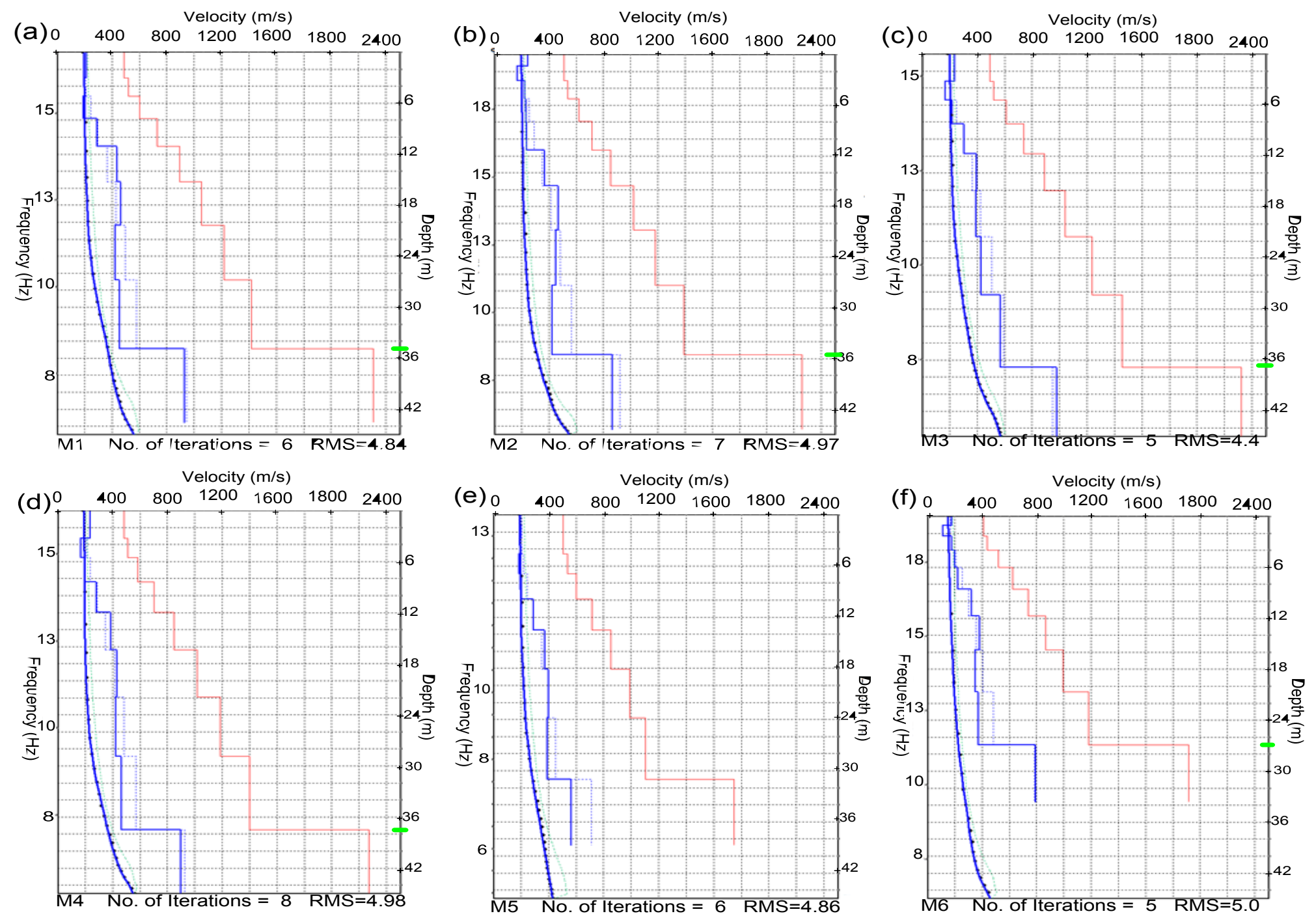

Figure 12. MASW results showing 1D shear wave $\left(\mathrm{V}_{\mathrm{S}}\right)$ and compressional wave $(\mathrm{Vp})$ velocity profiles. (a) M1 acquired at $33 \mathrm{~m}$ mark along P1. (b) M2 acquired at $100 \mathrm{~m}$ mark along P1. (c) M3 acquired at $162 \mathrm{~m}$ mark along P1. (d) M4 acquired at $225 \mathrm{~m}$ mark along P1. (d) M5 acquired at $318 \mathrm{~m}$ mark along P1. (d) M6 acquired in close proximity to Well 290586. Green marker on figure indicate interpreted depth to top of rock. M5 shows a low velocity subsurface compared to M1, M2, M3, M4, and M6. 


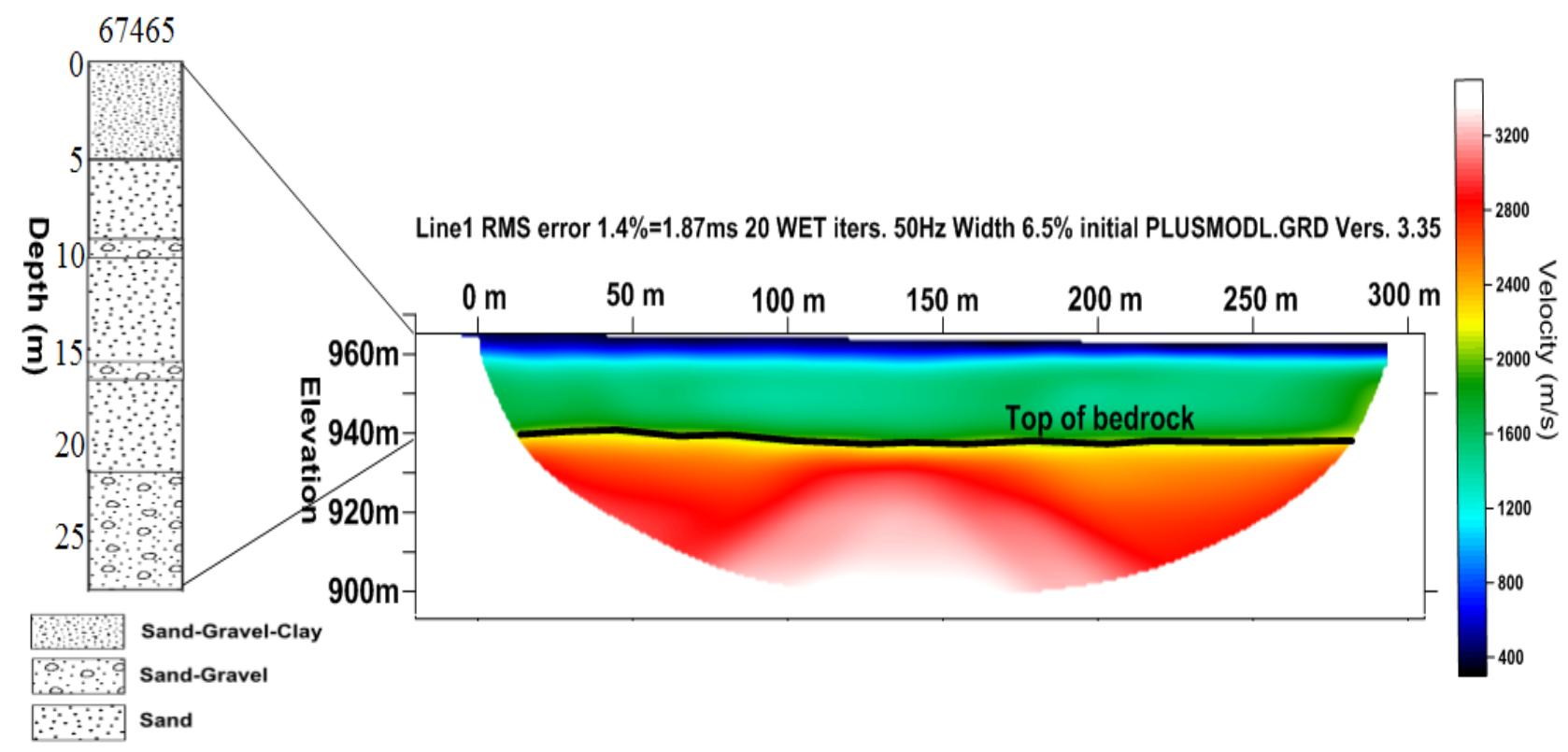

Figure 13. Velocity profile obtained from refraction seismic tomography using wavepath eikonal traveltime inversion (WET). Well 67465 located about $50 \mathrm{~m}$ west of the seismic profile is shown. Data for well 67465 are from MBMG's Groundwater Information Center (GWIC) database. 